\title{
MULTIPLE METALS EXPOSURE AND NEUROTOXIC RISK IN BALD EAGLES (HALIAEETUS LEUCOCEPHALUS) FROM TWO GREAT LAKES STATES
}

\author{
Dong-Ha Nam, Jennifer Rutkiewicz, and NiladRi Basu* \\ Department of Environmental Health Sciences, School of Public Health, University of Michigan, Ann Arbor, Michigan, USA
}

(Submitted 18 August 2011; Returned for Revision 2 October 2011; Accepted 25 October 2011)

\begin{abstract}
In the present study, the authors determined concentrations of several elements ( $\mathrm{As}, \mathrm{Cd}, \mathrm{Co}, \mathrm{Cu}, \mathrm{Cr}, \mathrm{Mn}, \mathrm{Pb}, \mathrm{Sb}, \mathrm{Zn}$ ) in the brains and livers of 46 bald eagles (Haliaeetus leucocephalus) from two Great Lakes states, Michigan and Minnesota. To explore whether exposures are of neurological concern, the authors assessed their associations with neurochemical receptors ( $N$-methyl-Daspartate [NMDA] and $\gamma$-aminobutyric acid A [GABA(A)]) and enzymes (glutamine synthetase [GS] and glutamic acid decarboxylase [GAD]) that play critical roles in vertebrate neurobehavior and reproduction. For most elements, levels in the livers and brains did not differ between region and gender. Hepatic $\mathrm{Pb}$ levels averaged $33.1 \mathrm{ppm}$ (dry wt), 30.4\% of all carcasses exceeded proposed avian $\mathrm{Pb}$ thresholds (>26.4 ppm), and in 30.8\% of the birds examined evidence of Pb pellets or fragments was found. Significant changes in the activities of GS and GAD were related to brain concentrations of several metals $(\mathrm{Pb}, \mathrm{Cd}, \mathrm{Co}, \mathrm{Cu}, \mathrm{Zn})$. No relationships were found among any of the nine elements and NMDA or GABA(A) receptor levels. When combined with the authors' previous study on these same eagles that showed $\mathrm{Hg}$-associated alterations in GS, GAD, and NMDA receptor levels, the present research suggests that bald eagles are exposed to various elements, especially $\mathrm{Pb}$ and $\mathrm{Hg}$, that are capable of causing changes in GABAergic and glutamatergic neurotransmission. The functional significance of these neurochemical changes warrants attention. Environ. Toxicol. Chem. 2012;31:623-631. (C) 2011 SETAC
\end{abstract}

Keywords-Neurochemical biomarkers Neurotoxicology Wildlife toxicology Heavy metals Brain Lead

\section{INTRODUCTION}

Bald eagles (Haliaeetus leucocephalus) are apex predators that bioaccumulate many environmental contaminants [1,2]. Studies on bald eagles across North America have documented appreciable levels of heavy metals, particularly $\mathrm{Hg}$, in their tissues [3-6]. Although $\mathrm{Hg}$ exposure and its potential neurological impacts in bald eagles have been recently documented $[7,8]$, much less is known about the exposure of eagles to other metals and potential neurological effects.

Animal neurobehavior and reproduction are influenced by brain neurochemistry, particularly by the neurotransmitters glutamate and $\gamma$-aminobutyric acid (GABA) $[9,10]$. Toxicantinduced changes in the function of neurochemical receptors and enzymes may result in subclinical effects that precede overt damage. Several wildlife studies have documented $\mathrm{Hg}$-associated changes to neurochemical receptors and enzymes [7,8,11-17]. In addition to $\mathrm{Hg}$, rodent studies have shown that several transition metals, such as $\mathrm{Cd}, \mathrm{Ag}, \mathrm{Co}, \mathrm{Cu}, \mathrm{Pb}, \mathrm{Mn}$, and $\mathrm{Zn}$, also impair neurochemical systems [18-20]. However, in the field of wildlife toxicology, the neurochemical effects of these other metals have been poorly studied.

Two recent studies on bald eagles showed significant associations between brain $\mathrm{Hg}$ levels and neurochemical receptors $(N$-methyl-D-aspartic acid [NMDA] receptor and muscarinic acetylcholine receptor) and enzymes (acetyl cholinesterase, glutamic acid decarboxylase [GAD], and glutamine synthetase [GS]) $[7,8]$, suggesting that $\mathrm{Hg}$ may be of neurological concern to this species. Although previous studies have shown significant tissue burdens (for example, in liver, kidney, and feathers

\footnotetext{
* To whom correspondence may be addressed (niladri@umich.edu).

Published online 14 December 2011 in Wiley Online Library (wileyonlinelibrary.com)
}

$[5,21])$ of other toxic and essential elements, few have explored levels in the brain and whether they may be of neurotoxicological concern. The present study was undertaken to determine concentrations of several elements $(\mathrm{Cr}, \mathrm{Mn}, \mathrm{Co}, \mathrm{Cu}, \mathrm{Zn}, \mathrm{As}, \mathrm{Cd}$, $\mathrm{Sb}, \mathrm{Pb}$ ) in brain and liver tissues of 46 wild bald eagles collected from two U.S. states in the Great Lakes region, Michigan and Minnesota. Furthermore, these elements were compared to neurochemical enzymes (GAD, GS) and receptors (NMDA, GABA) previously characterized by Rutkiewicz et al. [8] in these same tissues.

\section{MATERIALS AND METHODS}

\section{Animals}

Bald eagles used for the present study were part of another study concerning $\mathrm{Hg}$ exposure and neurochemical effects [8]. In the present study, we investigated a subset of carcasses $(n=46)$ that were selected from Michigan and Minnesota and matched according to available biological data (e.g., age, gender). Carcasses were provided by the Michigan Department of Natural Resources and Environment, The Raptor Center (University of Minnesota), and Minnesota Department of Natural Resources. From necropsy reports, birds died of various causes in the field (mainly trauma) or during rehabilitation. Carcasses were collected between 2002 and 2010 and stored at $-20^{\circ} \mathrm{C}$ until tissue collection. All necropsied birds were adults as determined by plumage. Of birds for which sex data were available, 12 were male and 18 were female. Extracted tissues were stored at $-80^{\circ} \mathrm{C}$ until all analyses. Proper U.S. Fish and Wildlife Service permits were obtained for this work.

\section{Elemental analysis}

Based on methods the authors published previously [22], the following elements were analyzed in whole brain and liver 
tissue: $\mathrm{Cr}, \mathrm{Mn}, \mathrm{Co}, \mathrm{Cu}, \mathrm{Zn}, \mathrm{As}, \mathrm{Cd}, \mathrm{Sb}$, and $\mathrm{Pb}$. Subsamples of liver and brain tissues were dried for $72 \mathrm{~h}$ at $60^{\circ} \mathrm{C}$, and then 0.1 to $0.3 \mathrm{~g}$ of the dried sample was digested with $1 \mathrm{ml}$ concentrated nitric acid $(70 \%$ nitric acid; Optima grade, Fisher Scientific) overnight at room temperature. The following day, each digest was heated for $1 \mathrm{~h}$ at $60^{\circ} \mathrm{C}$, and then for 3 to $5 \mathrm{~h}$ at $90^{\circ} \mathrm{C}$. The final digest was diluted with Milli-Q water to $2 \%$ nitric acid.

All elements were detected using an inductively coupled plasma mass spectrometer (Agilent 7500c, Agilent Technologies) equipped with a quadrupole analyzer and octopole collision/reaction cell pressurized with either a $\mathrm{H}_{2}$ or $\mathrm{He}$ reaction gas. Sample uptake was $0.4 \mathrm{ml} / \mathrm{min}$ from a peristaltic pump with 1.2 L/min Ar carrier gas through a Babbington-style nebulizer into a Peltier-cooled double-pass spray chamber at $2^{\circ} \mathrm{C} ; 1.0 \mathrm{~L} / \mathrm{min}$ auxiliary Ar and $12.0 \mathrm{~L} / \mathrm{min}$ plasma gas $\mathrm{Ar}$ were added for a total of $14.2 \mathrm{~L} / \mathrm{min}$ separated from nickel cones by a sampling depth of $8.5 \mathrm{~mm}$. The inductively coupled plasma mass spectrometer was tuned under standard settings by running the manufacturer's recommended tuning solution of $10 \mathrm{ppb}$ of $\mathrm{Li}, \mathrm{Y}, \mathrm{Ce}, \mathrm{Tl}$, and $\mathrm{Co}$ (Agilent internal standard mix) for resolution and sensitivity. Interference levels were reduced by optimizing plasma conditions to produce low oxide and doubly charged ions (formation ratio of $<1.0 \%$ ) and residual matrix interferences were removed using the collision/reaction processes in the Octopole Reaction System.

A series of rigorous analytical quality control measures were used. All biological samples were handled in a Class 100 and 1000 clean lab. Glassware, plasticware, and Teflon ${ }^{\circledR}$-coated tubes were acid-washed (cleaned, soaked in $10 \%$ nitric acid for $24 \mathrm{~h}$ ) prior to use. Accuracy and precision were measured using the Canadian National Research Council's DOLT-4. In addition, each batch run contained procedural blanks and replicate runs. Samples for which a contaminant was detected but with a concentration below the analytical detection limit were assigned a value of one-half the detection limit. For each particular element, the analytical detection limit was calculated as the concentration of the element that gave a detectable signal above the background noise at greater than the $99 \%$ confidence level, so that the detection limit was calculated as the mean of blanks plus three times the standard deviation of the mean. Detection limits were as follows: $\mathrm{Cr}(0.09 \mu \mathrm{g} / \mathrm{L}), \mathrm{Mn}(0.17 \mu \mathrm{g} / \mathrm{L})$, Co $(0.05 \mu \mathrm{g} / \mathrm{L}), \mathrm{Cu}(0.06 \mu \mathrm{g} / \mathrm{L}), \mathrm{Zn}(0.48 \mu \mathrm{g} / \mathrm{L})$, As $(0.01 \mu \mathrm{g} / \mathrm{L})$, $\mathrm{Cd}(0.05 \mu \mathrm{g} / \mathrm{L}), \mathrm{Sb}(0.01 \mu \mathrm{g} / \mathrm{L})$, and $\mathrm{Pb}(0.01 \mu \mathrm{g} / \mathrm{L})$. Accuracy (closeness to actual value) ranged from 92.4 to $116 \%$. The reproducibility (precision) of each element was within $6 \%$ of expected values.

\section{Neurochemical assays}

Cellular homogenates, enzyme supernatants, and membranes were prepared according to modifications of a procedure described by Rutkiewicz et al. [8] and Nam et al. [23]. Briefly, subsamples of brain (cerebrum) were homogenized in ice-cold Tris-buffer $\left(50 \mathrm{mM} \mathrm{NaH} \mathrm{PO}_{4}, 5 \mathrm{mM} \mathrm{KCl}, 120 \mathrm{mM} \mathrm{NaCl}, \mathrm{pH}\right.$ 7.4), and the supernatant was collected following a 15-min centrifugation at $15,000 \mathrm{~g}\left(4^{\circ} \mathrm{C}\right)$. Cellular membranes were then isolated by centrifuging the supernatant at $48,000 \mathrm{~g}$ for $15 \mathrm{~min}$ $\left(4^{\circ} \mathrm{C}\right)$, washing three times, and resuspending in buffer. The concentration of protein in the supernatant preparation was determined with the Bradford assay using bovine serum albumin as the standard. Prepared samples were stored at $-80^{\circ} \mathrm{C}$ until analysis.

Neurochemical enzyme activity for GS and GAD were measured according to procedures and technical equipment detailed by Rutkiewicz et al. [8]. For GS activity, assays were performed on supernatant $(400 \mu \mathrm{g}$ protein $/ \mathrm{ml}$; incubation at $37^{\circ} \mathrm{C}$ ) and absorbance $(500 \mathrm{~nm})$ was measured to determine $\gamma$-glutamyl hydroxymate concentration and specific activity. For GAD (as total) activity, the reaction mixture containing $100 \mu \mathrm{g}$ of protein was used. The reaction was started with the addition of $10 \mathrm{mM}$ glutamate containing $0.3 \mu \mathrm{Ci}\left[{ }^{14} \mathrm{C}\right]$-glutamic acid $(260 \mathrm{mCi} / \mathrm{mmol}$; PerkinElmer $)\left(45 \mathrm{~min}\right.$ incubation at $\left.37^{\circ} \mathrm{C}\right)$ and terminated with injection of $0.5 \mathrm{ml}$ of $0.25 \mathrm{M} \mathrm{HCl}(60 \mathrm{~min}$ incubation at $37^{\circ} \mathrm{C}$ ). After soaking in a scintillation cocktail (PerkinElmer), radioactivity was measured on a liquid scintillation counter (Wallac 1450 Microbeta Plus, PerkinElmer). Samples were assayed in triplicate and duplicate for GS and GAD, respectively. Both within and between-day variability averaged less than $20 \%$ for both assays. Enzyme activities were expressed as nanomoles/milligram/minute (GS activity) or femtomoles/milligram/hour (GAD activity).

Receptor binding assays were performed using cellular membranes according to previously published methods [8,23]. For both receptors, protein $(30 \mu \mathrm{g})$ was suspended in a $100 \mu \mathrm{l}$ buffer (NMDA: $50 \mathrm{mM}$ Tris buffer [pH 7.4] containing $100 \mu \mathrm{M}$ glycine and glutamate; GABA: $50 \mathrm{mM}$ Tris buffer [pH 7.4]). Samples were incubated at room temperature with $5 \mathrm{nM}\left[{ }^{3} \mathrm{H}\right] \mathrm{MK}-801$ $(27.5 \mathrm{Ci} / \mathrm{mmol})$ for $2 \mathrm{~h}$ (for NMDA) or on ice with $2 \mathrm{nM}$ $\left[{ }^{3} \mathrm{H}\right]$ flunitrazepam $(81.4 \mathrm{Ci} / \mathrm{mmol}$ ) for $30 \mathrm{~min}$ (for GABA). Nonspecific binding was determined through coincubation with $100 \mu \mathrm{M}$ unlabeled MK-801 (NMDA) or $20 \mu \mathrm{M}$ clonazepam (GABA). Samples were assayed in quadruplicate. Variability, which averaged less than $20 \%$, was monitored through internal, pooled controls. Binding is reported as femtomoles of radioisotope bound per milligram of membrane protein.

\section{Statistical analyses}

Data were analyzed using PASW Statistics (Ver 17.0). All concentrations are reported as mean \pm standard deviation on a dry weight basis unless otherwise noted. Preliminary analysis included descriptive statistics for all measures. Normality and homoscedasticity of data were tested by using the KolmogorovSmirnov test and the Levene's test ( $F_{\max }$ test), respectively. All tissue element concentrations were log-transformed prior to statistical analyses (one-way analysis of variance or $t$ tests). Pearson correlations were used to determine relationships between concentrations of tissue elements, as well as associations with neurochemical biomarkers. Quartile analyses were established using the mean ( \pm standard error) and the $25 \%$ and $75 \%$ interquartile $\mathrm{Pb}$ cutoffs, and were then used to compare the differences among quartiles of $\mathrm{Pb}$ measures following one-way analysis of variance. Associations among elements were analyzed using factor (principal component) analysis. A $p$ value of $<0.05$ was considered significant in all analyses.

\section{RESULTS}

Nine different elements were analyzed in the liver and brain tissue of 46 bald eagles (Table 1). The mean moisture content in the liver and brain was $66.1 \pm 5.8 \%$ and $79.7 \pm 3.4 \%$, respectively. In general, mean metal concentrations were higher in the liver than the brain. When stratified across sampling regions (Minnesota vs Michigan, and two regions within both states) and gender, no significant differences were detected in the liver or brain, except for brain $\mathrm{Mn}$ and brain $\mathrm{Zn}$, which exhibited regional differences (Table 1).

Correlative approaches were used to explore associations between concentrations of elements between the liver and the brain (Fig. 1), as well as among the elements in the liver (Table 2) 
and brain (Table 3). Lead, in particular, correlated with $\mathrm{Cd}, \mathrm{Sb}$, and $\mathrm{Zn}$ in the liver (Table 2), and with $\mathrm{Cd}, \mathrm{Cr}, \mathrm{Sb}$, and $\mathrm{Se}$ in the brain (Table 3). Many of the other elements correlated with each other in both tissues (Tables 2 and 3). Significant correlations among established toxic elements (As, $\mathrm{Cd}$, and $\mathrm{Pb}$ ) were observed between the liver and brain (Fig. 1).

Based on proposed threshold values from the literature [24-26], an opportunity was present here to put our hepatic tissue residue findings ( $\mathrm{As}, \mathrm{Cd}, \mathrm{Cu}, \mathrm{Hg}, \mathrm{Mn}, \mathrm{Pb}, \mathrm{Zn}$ ) into a broader context (Fig. 2). Residues of essential (e.g., $\mathrm{Cu}, \mathrm{Mn}, \mathrm{Zn}$ ) and toxic (e.g., As, Cd) hepatic elements were lower than proposed threshold values and were generally within ranges found in healthy animals including birds [24,25]. In contrast, hepatic levels of $\mathrm{Pb}$ averaged $33.1 \mathrm{ppm}$ (range: $0.20-215 \mathrm{ppm}$ ), and 14 of 46 eagles (30.4\% of the birds; average hepatic lead concentration: $104 \mathrm{ppm}$; range: 42.2-215 ppm) exceeded levels suggestive of $\mathrm{Pb}$ poisoning (26.4 ppm dry wt, assuming 70\% moisture content) in birds of prey [26]. Liver $\mathrm{Hg}$ concentrations in our previous results [8] exceeded the toxic threshold (16.7 ppm; [24]) in $26.1 \%$ of birds. When the $\mathrm{Pb}$ and $\mathrm{Hg}$ data are considered together, $10.8 \%$ of birds had hepatic levels of both toxic metals that exceeded suggested toxic thresholds.

Data were subjected to principal component analysis to determine if hepatic elements clustered in groups (Fig. 3). The first eigenvalue estimated from the matrix accounted for $28.6 \%$ of the total variance, and two eigenvalues explained $45.4 \%$ of the total variance. A diagnostic assessment of the scatterplots indicated two groups, the first consisting of $\mathrm{Pb}, \mathrm{Sb}$, and As, and the other comprising all other elements, including $\mathrm{Hg}$.

We previously analyzed a suite of neurochemical biomarkers in these same eagles in relation to $\mathrm{Hg}$ exposure [8], and the present study provided an opportunity to explore associations with other elements. There were no gender-associated differences in neurochemical biomarkers. Correlative approaches were used to assess the associations between logtransformed concentrations of elements in the brain and four neurochemical biomarkers (Table 4). Brain $\mathrm{Cu}$ and $\mathrm{Zn}$ were positively correlated with GS activity (Table 4 ). The activity of brain GAD was negatively correlated with $\mathrm{Co}, \mathrm{Cd}$, and $\mathrm{Pb}$. Multivariate analysis of the overall model indicated that GAD activity was most strongly related to $\mathrm{Pb}$, followed by $\mathrm{Cd}$, inorganic $\mathrm{Hg}$, and others (including methylmercury, total $\mathrm{Hg})(d f=11, F=330.18, p<0.05)$. Specific binding to the NMDA and GABA(A) (benzodiazepine) receptors did not correlate significantly with all elements investigated (Table 4).

Because of the high $\mathrm{Pb}$ exposures reported in the present study and the innate neurotoxic potential of $\mathrm{Pb}$ across vertebrates, the eagles were stratified into quartiles according to brain $\mathrm{Pb}$ levels. From this analysis, a significant decrease in GAD activity $(d f=3, F=3.1, p<0.05)$ was found between the first (range: $<0.75 \mathrm{ppm} \mathrm{Pb}$ ) and fourth (range: $6.4-18.3 \mathrm{ppm} \mathrm{Pb}$ ) quartile groups ( $\mathrm{n}=10$ or 11 per group) (Fig. 4). No significant changes were observed between $\mathrm{Pb}$ levels and other neurochemical biomarkers (Fig. 4).

Fluoroscopic analysis was used only in the birds from Michigan $(n=26)$, and eight individuals had $\mathrm{Pb}$ pellets or fragments (range: 1-19 pieces) in their digestive tracts. Although levels of tissue $\mathrm{Pb}$ in birds having confirmed $\mathrm{Pb}$ pellet exposures were higher than the other birds, this increase was not to a level of statistical significance (Table 1). Figure 5 shows associations of neurochemical biomarkers in relation to birds exposed to $\mathrm{Pb}$ shot. There were no changes of neurochemical biomarkers between birds that were negative and birds that were positive for $\mathrm{Pb}$ shot. 

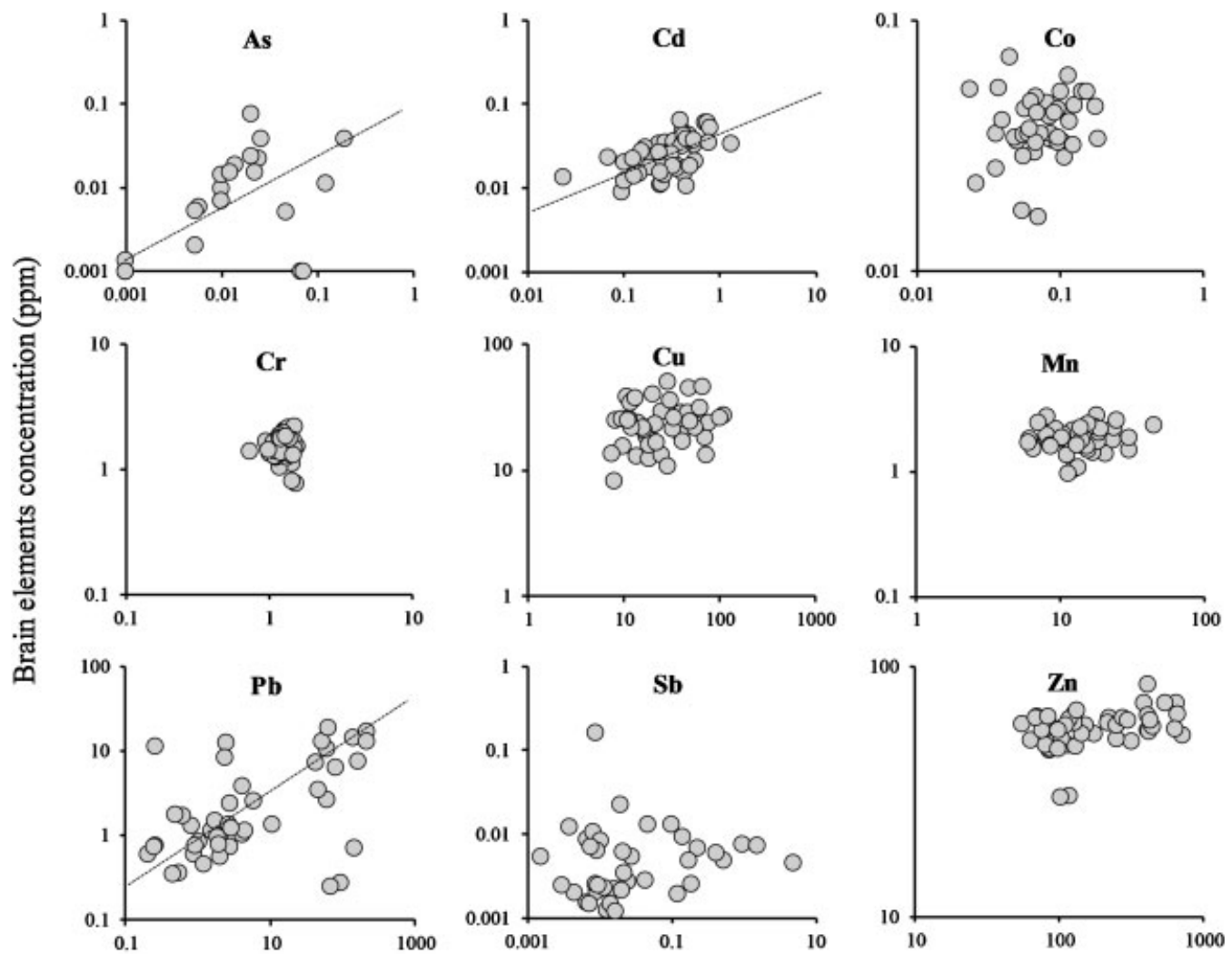

Liver elements concentration (ppm)

Fig. 1. Correlation of elements between liver and brain in bald eagles (Haliaeetus leucocephalus). Statistically significant correlations were found for As $(r=0.377, p<0.05), \mathrm{Cd}(r=0.544, p<0.001)$, and $\mathrm{Pb}(r=0.583, p<0.001)$.

\section{DISCUSSION}

To our knowledge, this is the first report outlining concentrations of several elements, including heavy metals of ecologic and neurotoxic concern, in the brain tissue of bald eagles. The major findings were that $30.4 \%$ of all carcasses investigated had $\mathrm{Pb}$ residues associated with intoxication $(>26.4 \mathrm{ppm}$ dry $\mathrm{wt})$ and that significant changes of physiologically important neurochemical enzymes (GS, GAD) were related to brain concentrations of $\mathrm{Pb}, \mathrm{Cd}, \mathrm{Co}, \mathrm{Cu}$, and $\mathrm{Zn}$.

The threat of $\mathrm{Pb}$ intoxication has been well documented in raptors, including bald eagles. This concern largely arises from the ingestion of $\mathrm{Pb}$ shot projectiles or fragments embedded in their prey. In our study, concentrations of hepatic $\mathrm{Pb}$ (mean:
$33.1 \mathrm{ppm}$; range: $0.20-215 \mathrm{ppm}$ ) are comparable to values suggestive of $\mathrm{Pb}$ poisoning in some raptorial species [26], including the bald eagle [27,28], golden eagle (Aquila chrysaetos) [28], and white-tailed eagle (Haliaeetus albicilla) [29]. A conservative liver threshold for toxic effects in some birds of prey, especially Falconiformes, is proposed to be 26.4 ppm [26]. In the present study, $30.4 \%$ of eagles investigated exceeded this value. Lead is an established neurotoxicant, and severe $\mathrm{Pb}$ intoxication can cause neuropathological damage in the brain (encephalopathy) manifested by an impairment of the bloodbrain barrier [30]. Brain $\mathrm{Pb}$ was significantly correlated with hepatic $\mathrm{Pb}$ levels (Fig. 1). The resulting regression equation $\left(Y=1.142 x^{0.5721}\right.$, where $Y=$ brain $\mathrm{Hg}$ and $x=$ liver $\mathrm{Hg}$ ) enabled us to predict a brain threshold for toxicity of approximately

Table 2. Correlation matrix among hepatic elements ${ }^{\mathrm{a}}$

\begin{tabular}{|c|c|c|c|c|c|c|c|c|c|c|}
\hline & As & $\mathrm{Cd}$ & Co & $\mathrm{Cr}$ & $\mathrm{Cu}$ & $\mathrm{Hg}$ & $\mathrm{Mn}$ & $\mathrm{Pb}$ & $\mathrm{Sb}$ & $\mathrm{Se}$ \\
\hline $\mathrm{Cd}$ & $0.313^{*}$ & - & - & - & - & - & - & - & - & - \\
\hline Co & -0.091 & $0.292^{*}$ & - & - & - & - & - & - & - & - \\
\hline $\mathrm{Cu}$ & -0.096 & $0.364^{*}$ & $0.390^{* *}$ & 0.037 & - & - & - & - & - & - \\
\hline $\mathrm{Hg}$ & -0.127 & $0.405^{*}$ & 0.261 & 0.164 & $0.367^{*}$ & - & - & - & - & - \\
\hline $\mathrm{Mn}$ & 0.250 & $0.358^{*}$ & 0.287 & 0.120 & 0.138 & 0.227 & - & - & - & - \\
\hline $\mathrm{Pb}$ & 0.006 & $0.300^{*}$ & 0.104 & -0.121 & 0.273 & 0.171 & 0.263 & - & - & - \\
\hline $\mathrm{Zn}$ & -0.055 & $0.438^{* *}$ & $0.443^{* *}$ & -0.001 & $0.305^{*}$ & $0.408^{* *}$ & $0.724^{* * *}$ & $0.458^{* *}$ & 0.132 & 0.227 \\
\hline
\end{tabular}

${ }^{\text {a }}$ Mercury $(\mathrm{Hg})$ and Se data were obtained from the study of Rutkiewicz et al. [8].

${ }^{*} p<0.05$

${ }^{* *} p<0.01$

${ }^{* *} p<0.001$. 
Table 3. Correlation matrix among brain elements ${ }^{\mathrm{a}}$

\begin{tabular}{|c|c|c|c|c|c|c|c|c|c|c|}
\hline & As & $\mathrm{Cd}$ & Co & $\mathrm{Cr}$ & $\mathrm{Cu}$ & $\mathrm{Hg}$ & $\mathrm{Mn}$ & $\mathrm{Pb}$ & $\mathrm{Sb}$ & $\mathrm{Se}$ \\
\hline $\mathrm{Cd}$ & 0.090 & - & - & - & - & - & - & - & - & - \\
\hline $\mathrm{Co}$ & -0.132 & 0.164 & - & - & - & - & - & - & - & - \\
\hline $\mathrm{Cr}$ & 0.027 & $0.387^{* *}$ & 0.265 & - & - & - & - & - & - & - \\
\hline $\mathrm{Cu}$ & 0.224 & 0.118 & 0.130 & 0.094 & - & - & - & - & - & - \\
\hline $\mathrm{Hg}$ & 0.164 & $0.376^{*}$ & -0.019 & 0.078 & 0.218 & - & - & - & - & - \\
\hline $\mathrm{Mn}$ & -0.105 & -0.210 & $0.341^{*}$ & $0.452^{* *}$ & 0.210 & -0.154 & - & - & - & - \\
\hline $\mathrm{Pb}$ & -0.018 & $0.360^{*}$ & 0.198 & $0.313^{*}$ & 0.050 & 0.046 & 0.063 & - & - & - \\
\hline $\mathrm{Sb}$ & 0.002 & 0.011 & 0.136 & 0.269 & -0.238 & 0.029 & 0.194 & $0.327^{*}$ & - & - \\
\hline $\mathrm{Se}$ & $0.407^{* *}$ & $0.499^{* *}$ & 0.187 & 0.278 & $0.447^{* *}$ & $0.597^{* * *}$ & 0.053 & $0.303^{*}$ & -0.030 & - \\
\hline $\mathrm{Zn}$ & 0.010 & -0.106 & $0.472^{* *}$ & 0.290 & $0.323^{*}$ & -0.076 & $0.591^{* * *}$ & 0.237 & 0.069 & 0.194 \\
\hline
\end{tabular}

${ }^{\mathrm{a}}$ Mercury $(\mathrm{Hg})$ and Se data were obtained from the study of Rutkiewicz et al. [8].

${ }^{*} p<0.05$;

${ }^{* *} p<0.01$;

*** $p<0.001$.

$6.4 \mathrm{ppm}$ (associated with $26.4 \mathrm{ppm}$ in liver), which was exceeded by $23.9 \%$ of eagles in this study. These results suggest that tissue $\mathrm{Pb}$ residues are of toxicological or neurotoxicological concern in a sizeable number of bald eagles across the Great Lakes region (Michigan and Minnesota).

Legislative action has imposed restrictions on the use of $\mathrm{Pb}$ shot for hunting in several regions, but because of the modern and historical ubiquity of $\mathrm{Pb}$ shot use and the persistence of $\mathrm{Pb}$ in the environment, $\mathrm{Pb}$ exposure is still of concern to wildlife across North America. The U.S. Environmental Protection Agency (U.S. EPA) estimated that in 2005 approximately 80,000 tons of $\mathrm{Pb}$ shot entered the U.S. environment from shooting ranges (http://www.epa.gov/Region2/waste/leadshot/ epa_mp.pdf). Our findings, via fluoroscopy or confirmed observations, demonstrated that $30.8 \%$ of adult carcasses collected from Michigan had $\mathrm{Pb}$ pellets or fragments in their digestive tracts. Though birds with confirmed $\mathrm{Pb}$ exposures (as $\mathrm{Pb}$ shot

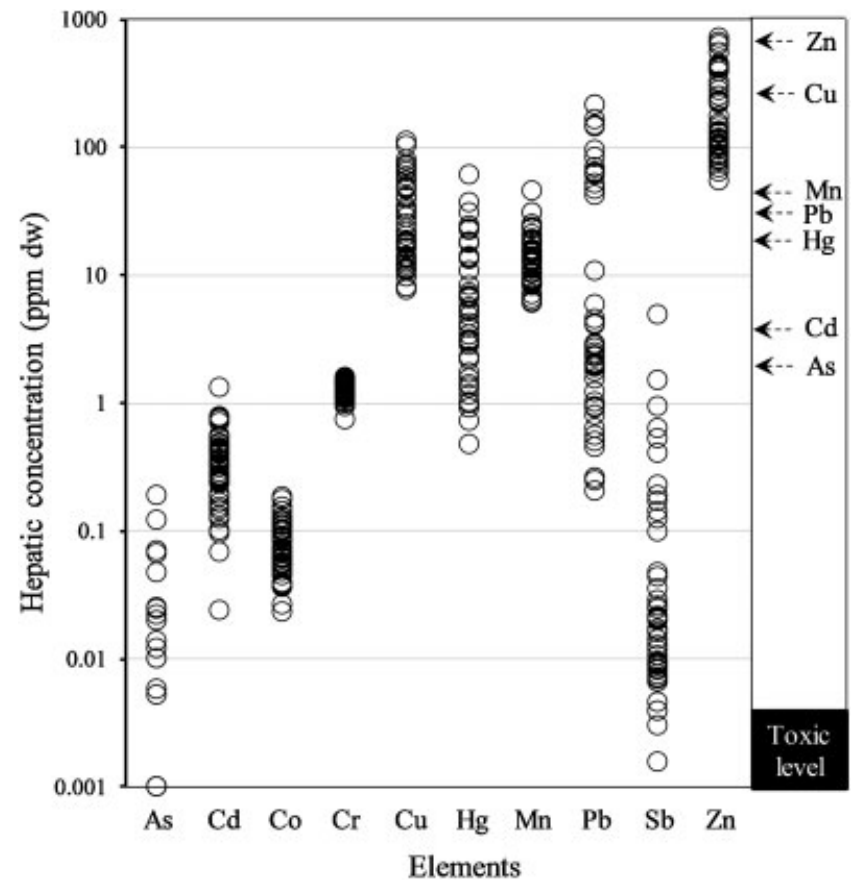

Fig. 2. Hepatic concentrations of elements ( $\mathrm{Hg}$ data from Rutkiewicz et al. [8]) in bald eagles (Haliaeetus leucocephalus) in relation to risk threshold values proposed by Zillioux et al. [24], Puls [25], and Beyer et al. [26]. presence) had higher levels in their tissues, similar hepatic and brain $\mathrm{Pb}$ residues were found between the two groups (Table 1). This lack of statistical difference may be related to a low sample size, extensive $\mathrm{Pb}$ exposure to general eagle populations regardless of $\mathrm{Pb}$ uptake pathway (e.g., direct consumption of $\mathrm{Pb}$ fragments through their prey or secondary uptake of $\mathrm{Pb}$ from $\mathrm{Pb}$-contaminated prey), as well as some uncertainty regarding the residency time and subsequent kinetics of $\mathrm{Pb}$ tissue distribution of the observed/fluoroscoped $\mathrm{Pb}$ shot in each animal.

The metallic formulation of $\mathrm{Pb}$ shots vary, but they generally comprise $\mathrm{Pb}(>90 \%)$, with some $\mathrm{Sb}(1-5 \%)$, and other elements (As, $\mathrm{Cu}, \mathrm{Ni}$, and $\mathrm{Zn}$ ) [31]. Antimony ( $\mathrm{Sb}$ ) is used primarily as a hardener for $\mathrm{Pb}$ ammunition. Although several wildlife toxicology studies have characterized $\mathrm{Pb}$ exposure, fewer have explored Sb levels. In our study, concentrations of $\mathrm{Sb}$ in livers and brains averaged $0.225 \mathrm{ppm}$ (range: $0.005-4.89 \mathrm{ppm}$ ) and $0.008 \mathrm{ppm}$ (range: $0.001-0.161 \mathrm{ppm}$ ), respectively (Table 1 ). Antimony concentrations were significantly associated with $\mathrm{Pb}$ levels in both liver and brain (Tables 2 and 3), thus suggesting coexposures to $\mathrm{Pb}$ and $\mathrm{Sb}$. Although $\mathrm{Sb}$ and its compounds are environmental pollutants suspected of being genotoxic and carcinogenic [32,33], very few studies have reported on $\mathrm{Sb}$

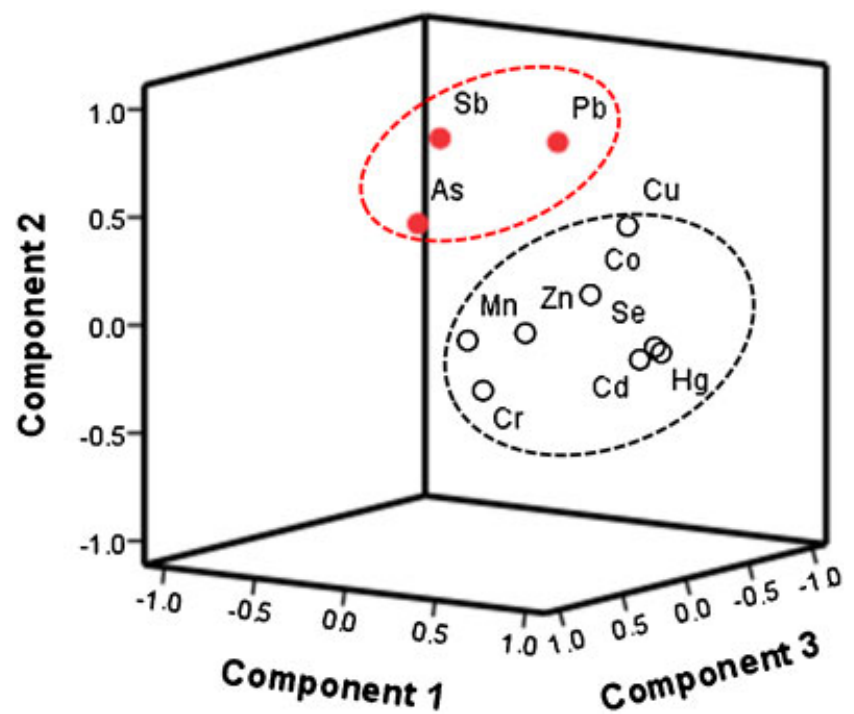

Fig. 3. Principal component analysis of hepatic elements. Two groupings are apparent: (1) $\mathrm{As}, \mathrm{Pb}$, and $\mathrm{Sb}$ and (2) all other elements including $\mathrm{Hg}$. [Color figure can be seen in the online version of this article, available at wileyonlinelibrary.com.] 
Table 4. Correlations between elemental concentrations and neurochemicals (enzymes and receptors) in the brains of wild bald eagles (Haliaeetus leucocephalus $)^{\mathrm{a}}$

\begin{tabular}{|c|c|c|c|c|c|c|c|c|}
\hline & \multicolumn{2}{|c|}{ GS activity $(n=44)$} & \multicolumn{2}{|c|}{ GAD activity $(n=41)$} & \multicolumn{2}{|c|}{$\begin{array}{l}\text { NMDAR binding } \\
(n=46)\end{array}$} & \multicolumn{2}{|c|}{$\begin{array}{c}\mathrm{GABA}(\mathrm{A}) \mathrm{R} \text { binding } \\
(n=46)\end{array}$} \\
\hline & $r$ & $p$ & $r$ & $p$ & $r$ & $p$ & $r$ & $p$ \\
\hline $\mathrm{Cr}$ & 0.137 & 0.375 & -0.161 & 0.314 & -0.166 & 0.271 & 0.093 & 0.537 \\
\hline Mn & 0.148 & 0.339 & 0.252 & 0.112 & -0.192 & 0.201 & 0.116 & 0.444 \\
\hline $\mathrm{Co}$ & 0.124 & 0.421 & -0.361 & 0.020 & 0.252 & 0.091 & -0.034 & 0.824 \\
\hline $\mathrm{Cu}$ & 0.323 & 0.033 & -0.105 & 0.515 & 0.106 & 0.484 & -0.012 & 0.935 \\
\hline $\mathrm{Zn}$ & 0.375 & 0.012 & -0.162 & 0.311 & 0.118 & 0.436 & 0.114 & 0.449 \\
\hline As & 0.085 & 0.585 & -0.291 & 0.065 & -0.205 & 0.171 & 0.094 & 0.533 \\
\hline $\mathrm{Cd}$ & 0.086 & 0.580 & -0.375 & 0.016 & 0.058 & 0.704 & -0.187 & 0.213 \\
\hline $\mathrm{Sb}$ & 0.04 & 0.798 & -0.061 & 0.704 & -0.192 & 0.202 & 0.236 & 0.114 \\
\hline $\mathrm{Pb}$ & -0.051 & 0.744 & -0.342 & 0.029 & 0.202 & 0.179 & 0.293 & 0.053 \\
\hline $\mathrm{IHg}$ & 0.188 & 0.030 & -0.196 & 0.030 & -0.282 & 0.001 & 0.026 & 0.771 \\
\hline
\end{tabular}

${ }^{a}$ Inorganic mercury $(\mathrm{Hg})$ data were obtained from the study of Rutkiewicz et al. [8].

$\mathrm{GS}=$ glutamine synthetase $\mathrm{GAD}=$ glutamic acid decarboxylase; NMDA $=N$-methyl-D-aspartate; GABA(A) $=\gamma$-aminobutyric acid A.

bioaccumulation and its potential risks to wild birds. A recent study shows that hepatic Sb levels in tinamou species from a polluted site (for example, a mining area) ranged from 0.03 to $0.20 \mathrm{ppm}$ (mean, $0.06 \mathrm{ppm}$ ), and that $\mathrm{Sb}$ exposure in these birds was 10 to 20 times higher than in control birds [33]. Despite tremendous variations of hepatic $\mathrm{Sb}$ in the bald eagles from the present study, $19.5 \%$ of birds had more than $0.20 \mathrm{ppm}$ in the liver, which was the highest $\mathrm{Sb}$ level found in the mine-exposed tinamou.

There were significant correlations among toxic elements $(\mathrm{Pb}, \mathrm{Cd}, \mathrm{Hg}, \mathrm{Cr}$, or $\mathrm{As})$ within the liver and within the brain (Tables 2 and 3). In addition, some toxic elements, such as As, $\mathrm{Cd}$, and $\mathrm{Pb}$, were positively correlated between the liver and brain (Fig. 1). Although further studies are required to resolve exposure pathways of each element, at least in some parts, the data presented here show elevated exposure to toxic $\mathrm{Pb}$ and $\mathrm{Sb}$ (including relatively low As) that may be associated with $\mathrm{Pb}$ shot ingestion. This is supported by examining the outcome of our principal component analysis (Fig. 3), in which two eigenvalues explained $45.4 \%$ of the total variance and resulted in two groups, the first consisting of $\mathrm{Pb}, \mathrm{Sb}$, and $\mathrm{As}$, and the other comprising all other elements. By including $\mathrm{Hg}$ data from these same birds [8], we identify both $\mathrm{Pb}$ and $\mathrm{Hg}$ as being present at high levels in some cases $(10.8 \%$ of birds had toxic levels of both heavy metals). Both are ubiquitous pollutants in the Great Lakes ecosystem. From the principal component analysis, the
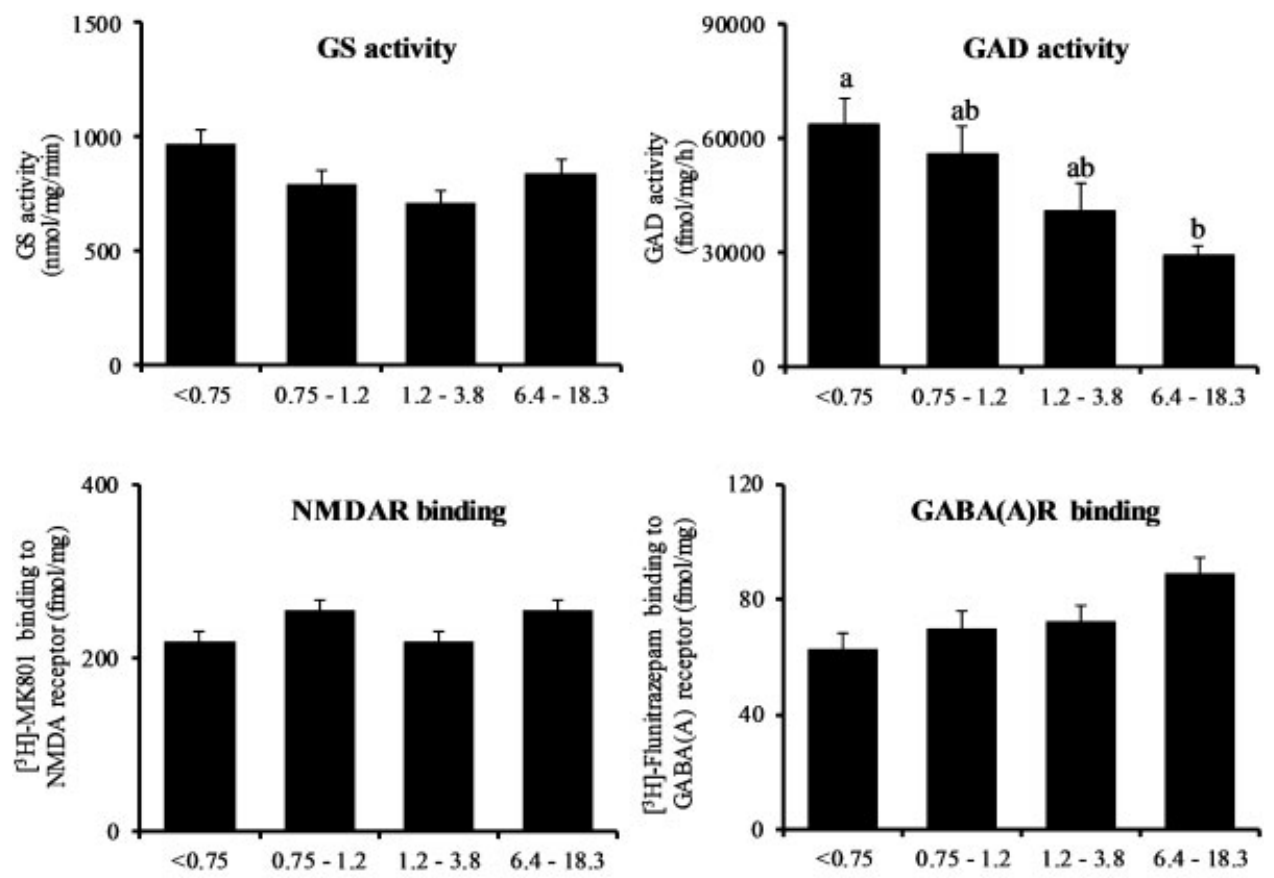

Brain $\mathrm{Pb}$ levels (ppm; quartile ranges)

Fig. 4. Mean ( \pm standard error) neurochemical enzyme activities and receptor levels in bald eagles (Haliaeetus leucocephalus) separated into brain quartiles of Pb exposure $(n=10$ or 11 per group for glutamine synthetase [GS] and glutamic acid decarboxylase [GAD] activities; $n=11$ or 12 per group for $N$-methyl D-aspartate [NMDA] and $\gamma$-aminobutyric acid A [GABA(A)] receptor levels). Letters denote significant differences $(p<0.05)$ among the bars following one-way analysis of variance. 


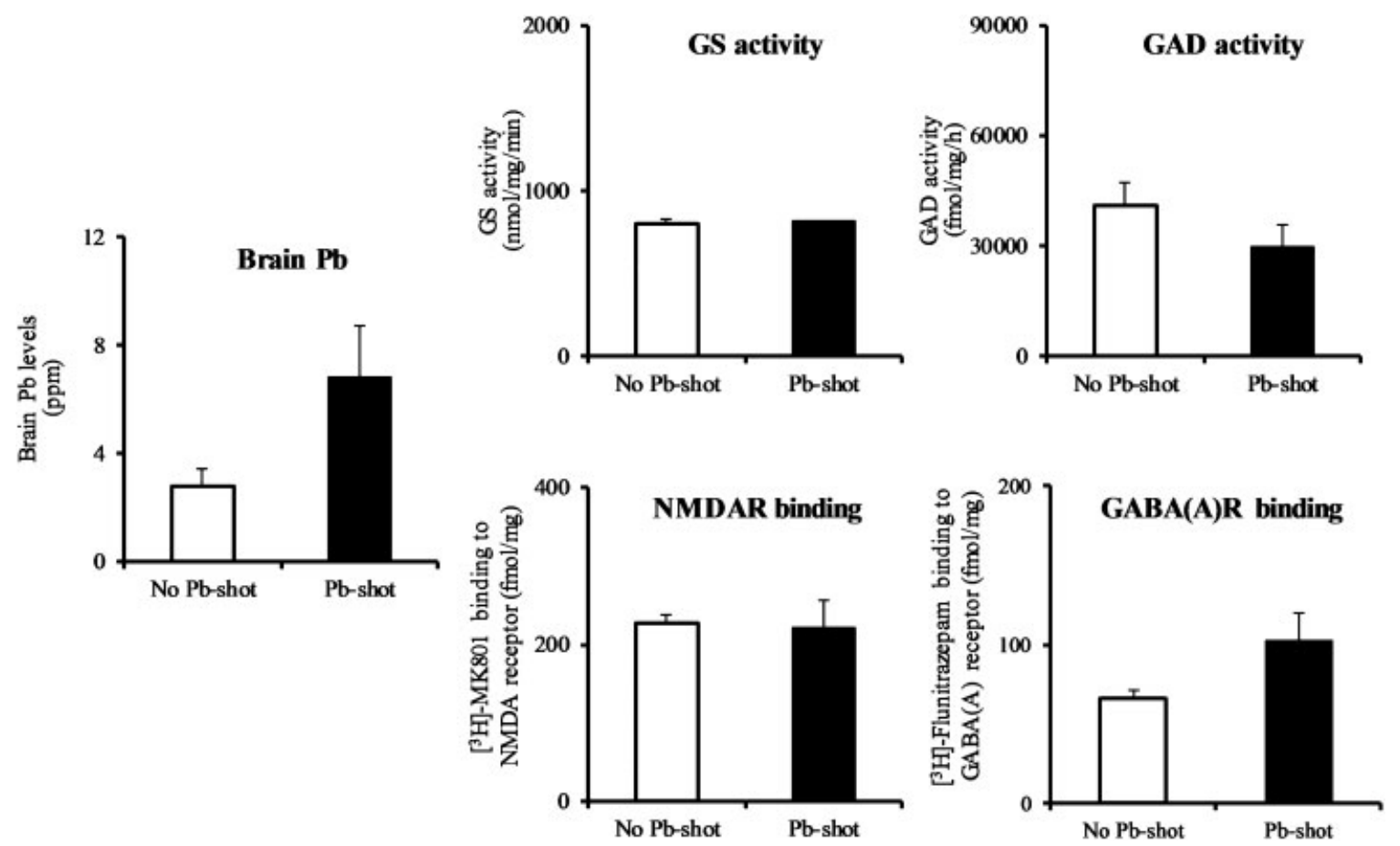

Fig. 5. Comparisons of brain $\mathrm{Pb}$ levels and four neurochemical biomarkers (mean \pm standard error) between $\mathrm{Pb}$-shot-negative $(n=18)$ and $\mathrm{Pb}$-shot-positive $(n=8)$ cases from Michigan bald eagles (Haliaeetus leucocephalus). GS = glutamine synthetase; GAD = glutamic acid decarboxylase; NMDA $=$ N-methyl D-aspartate; $\operatorname{GABA}(\mathrm{A})=\gamma$-aminobutyric acid A.

source-exposure routes for $\mathrm{Pb}$ may be differentiated from $\mathrm{Hg}$ in bald eagles (likely $\mathrm{Pb}$ shot ingestion vs fish consumption). Both $\mathrm{Pb}$ and $\mathrm{Hg}$ are proven neurotoxicants, but little is known about their cumulative impacts on avian health.

The neurotransmitters glutamate and GABA have critical roles in vertebrate reproduction and neurobehavior [34]. Here, $\mathrm{Pb}-, \mathrm{Cd}-$, and Co-associated decreases in GAD activity were found (Table 4). Because of high $\mathrm{Pb}$ exposure and its neurotoxic potential, the eagles were stratified into quartiles according to brain Pb levels. For GAD, the difference in mean enzyme activity between the lowest $(<0.75 \mathrm{ppm})$ and highest (>6.4 ppm) Pb quartile was $54.2 \%$ (Fig. 4). Reduction in GAD activity has been observed in Pb-exposed organisms [34].

For the $\operatorname{GABA}(\mathrm{A})$ receptor, we found a $42 \%$ increase in receptor density in the highest $(>6.4 \mathrm{ppm} \mathrm{Pb})$ quartile when compared to the lowest $(<0.75 \mathrm{ppm} \mathrm{Pb})$ quartile (Fig. 4). There was also a positive correlation between $\operatorname{GABA}(\mathrm{A})$ receptor levels and brain $\mathrm{Pb}$ levels (Table 4; $r=0.293, p=0.053$ ); however, his correlation was not to a level of statistical significance. Although $\mathrm{Co}, \mathrm{Cd}$, and $\mathrm{Hg}$ were negatively associated with GAD activity (Table 4), no increasing trends of GABA(A) receptor levels were found by quartile analysis (data not shown). Increases in $\operatorname{GABA}(\mathrm{A})$ receptor density have been documented in response to a $\mathrm{Pb}$-induced inhibition of GABA release in rodents [35]. In the present study, the GAD inhibition by aforementioned metals (Table 1), as well as a significant negative correlation between GAD activity and GABA(A) receptor levels $(r=-0.352, p<0.05)$, suggests that GABAergic components in wild bald eagles may be modulated following exposures to environmental elements, especially $\mathrm{Pb}$.

Glutamine synthetase catalyzes the metabolic degradation of glutamate to glutamine. This enzyme, together with glutamate uptake transporters, tightly regulates extracellular glutamate to ensure homeostasis and prevent glutamate-mediated excitotoxic damage. We have recently completed a series of studies (in vitro using isolated synaptosomes, field-based collection of brain tissues, and controlled laboratory bioassays) across several species of fish, birds, and mammals to document that environmentally relevant levels of $\mathrm{Hg}$ can inhibit glutamate uptake (D-H. Nam and N. Basu, University of Michigan, unpublished data), which would lead to a build-up of glutamate in the synapse. Our present (Table 4) and previous results [8] showed that GS activity significantly increased in association with brain $\mathrm{Zn}, \mathrm{Cu}$, and $\mathrm{Hg}$. In mammals, high concentrations of extracellular glutamate, which is neurotoxic, increases GS expression, resulting in increased uptake of glutamate into astrocytes [36]. Though $\mathrm{Zn}$ and $\mathrm{Cu}$ are essential metals in the brain, $\mathrm{Zn}(>100 \mu \mathrm{M})$ and $\mathrm{Cu}(25 \mu \mathrm{M})$ can inhibit astrocyte glutamate uptake by poly(ADP-ribose) polymerase- 1 activation [37] and hydroxyl radicals [38], respectively. Increases in GS activity are likely an adaptive cellular response to $\mathrm{Zn}, \mathrm{Cu}$, and $\mathrm{Hg}$ exposure to ensure that synaptic glutamate levels remain within a physiological range and do not lead to excitotoxic damage.

The NMDA receptor is the main excitatory neurotransmitter receptor in the vertebrate nervous system [39]. In the present study, we observed no relationship between concentrations of brain elements and NMDA receptor levels (Table 4). However, in these same bald eagles, we had previously found a significant decrease in NMDA receptor levels $(\mathrm{n}=128, r=-0.245$, $p<0.01$ ) associated with brain total $\mathrm{Hg}$ (mean: $2.8 \mathrm{ppm}$; range: 0.2-34 ppm) (Table 4; [8]). A negative correlation has also been found between $\mathrm{Hg}$ and NMDA receptor levels in a range of wild (e.g., mink, polar bear, bald eagle) and laboratory (e.g., captive mink) animals $[7,16,17]$. These results suggest that the decrease in NMDA receptor levels may represent a compensatory scheme to cope with $\mathrm{Hg}$-associated excitotoxic damage.

An important limitation of this work is the recognition that neurochemical biomarkers vary in their postmortem stability. We have addressed this previously [40], and in a forthcoming 
laboratory-based study we have specifically addressed the four biomarkers studied here (J. Rutkiewicz and N. Basu, University of Michigan, unpublished data). In general, $\left[{ }^{3} \mathrm{H}\right] \mathrm{MK}-801$ binding to the NMDA receptor was quite stable under all postmortem conditions tested (temperature, time, freeze-thaw cycles), GAD activity exhibited some stability, and binding to the $\operatorname{GABA}(\mathrm{A})$ receptor and GS activity exhibited poor stability. These postmortem stability data need to be considered when interpreting the results presented in the present study.

In conclusion, our results show that bald eagles are exposed to various elements, especially $\mathrm{Pb}$ and $\mathrm{Hg}$, that may be present at toxic levels to a sizeable number of birds. The concentrations found in brain and associations with neurochemical biomarkers suggest that levels may be sufficient to alter GABAergic and glutamatergic signaling. Because of the fundamental roles of these neurotransmitter pathways in vertebrate neurobehavior and reproduction, prolonged neurochemical alterations may impact wildlife health. These findings raise further questions about the ecological and physiological impacts of metals in the environment and their impact on wild bald eagle populations.

Acknowledgement-We thank collaborators within the Michigan Department of Natural Resources and Environment (T. Cooley), the University of Minnesota Raptor Center (I. Bueno Padilla), and the Minnesota Department of Natural Resources (L. Shen, R. Bhagyam) for their assistance in the collection and dissection of eagle carcasses. J. Rutkiewicz was funded by a University of Michigan Regents Fellowship. Funding for the study was provided by grants to N. Basu from the University of Michigan School of Public Health and the Great Lakes Air Deposition program.

\section{REFERENCES}

1. Bowerman WW, Best DA, Grubb TG, Sikarskie JG, Giesy JP. 2000. Assessment of environmental endocrine disruptors in bald eagles of the Great Lakes. Chemosphere 41:1569-1574.

2. Bowerman WW, Best DA, Giesy OP, Shieldcastle MC, Meyer MW, Postupalsky S, Sikarskie JG. 2003. Associations between regional differences in polychlorinated biphenyls and dichlorodiphenyldichloroethylene in blood of nestling bald eagles and reproductive productivity. Environ Toxicol Chem 22:371-376.

3. Wayland M, Neugebauer E, Bollinger T. 1999. Concentrations of lead in liver, kidney, and bone of bald and golden eagles. Arch Environ Contam Toxicol 37:267-272.

4. Miller MJ, Wayland ME, Bortolotti GR. 2001. Exposure of migrant bald eagles to lead in prairie Canada. Environ Pollut 112:153-162.

5. Stout JH, Trust KA. 2002. Elemental and organochlorine residues in bald eagles from Adak Island, Alaska. $J$ Wildl Dis 38:511-517.

6. Desmarchelier M, Santamaria-Bouvier A, Fitzgérald G, Lair S. 2010. Mortality and morbidity associated with gunshot in raptorial birds from the province of Quebec: 1986 to 2007. Can Vet J 51:70-74.

7. Scheuhammer AM, Basu N, Burgess NM, Elliott JE, Campbell GD, Wayland M, Champoux L, Rodrigue J. 2008. Relationships among mercury, selenium, and neurochemical parameters in common loons (Gavia immer) and bald eagles (Haliaeetus leucocephalus). Ecotoxicology 17:93-101.

8. Rutkiewicz J, Nam DH, Cooley T, Neumann K, Padilla IB, Route W, Strom S, Basu N. 2011. Mercury exposure and neurochemical impacts in bald eagles across several Great Lakes states. Ecotoxicology 20: $1669-1676$

9. Trudeau VL, Spanswick D, Fraser EJ, Lariviere K, Crump D, Chiu S, MacMillan M, Schulz RW. 2000. The role of amino acid neurotransmitters in the regulation of pituitary gonadotropin release in fish. Biochem Cell Biol 78:241-259.

10. Gibbs ME, Johnston GA. 2005. Opposing roles for GABAA and GABAC receptors in short-term memory formation in young chicks. Neuroscience 131:567-576.

11. Basu N, Klenavic K, Gamberg M, O'Brien M, Evans D, Scheuhammer AM, Chan HM. 2005. Effects of mercury on neurochemical receptorbinding characteristics in wild mink. Environ Toxicol Chem 24: 1444-1450.

12. Basu N, Stamler CJ, Loua KM, Chan HM. 2005. An interspecies comparison of mercury inhibition on muscarinic acetylcholine receptor binding in the cerebral cortex and cerebellum. Toxicol Appl Pharmacol 205:71-76.

13. Basu N, Kwan M, Chan HM. 2006. Mercury but not organochlorines inhibits muscarinic cholinergic receptor binding in the cerebrum of ringed seals (Phoca hispida). J Toxicol Environ Health A 69:1133-1143.

14. Basu N, Scheuhammer AM, Rouvinen-Watt K, Grochowina N, Klenavic K, Evans RD, Chan HM. 2006. Methylmercury impairs components of the cholinergic system in captive mink (Mustela vison). Toxicol Sci 91:202-209.

15. Basu N, Scheuhammer AM, Evans RD, O’Brien M, Chan HM. 2007. Cholinesterase and monoamine oxidase activity in relation to mercury levels in the cerebral cortex of wild river otters. Hum Exp Toxicol 26:213-220.

16. Basu N, Scheuhammer AM, Rouvinen-Watt K, Grochowina N, Evans RD, O'Brien M, Chan HM. 2007. Decreased N-methyl-D-aspartic acid (NMDA) receptor levels are associated with mercury exposure in wild and captive mink. Neurotoxicology 28:587-593.

17. Basu N, Scheuhammer AM, Sonne C, Letcher RJ, Born EW, Dietz R. 2009. Is dietary mercury of neurotoxicological concern to wild polar bears (Ursus maritimus)? Environ Toxicol Chem 28:133-140.

18. Aronstam RS, Elderfrawi ME. 1979. Transition and heavy metal inhibition of ligand binding to muscarinic acetylcholine receptors from rat brain. Toxicol Appl Pharmacol 48:489-496.

19. Reynolds IJ, Miller RJ. 1988. [3H]MK801 binding to the NMDA receptor/ionophore complex is regulated by divalent cations: Evidence for multiple regulatory sites. Eur J Pharmacol 151:103-112.

20. Shellenberger MK. 1984. Effects of early lead exposure on neurotransmitter systems in the brain. A review with commentary. Neurotoxicology 5: 177-212.

21. Bechard MJ, Perkins DN, Kaltenecker GS, Alsup S. 2009. Mercury contamination in Idaho bald eagles, Haliaeetus leucocephalus. Bull Environ Contam Toxicol 83:698-702.

22. Basu N, Nam D-H, Kwansah-Ansah E, Renne E, Nriagu J. 2011 Multiple metals exposures among small-scale artisanal gold miners. Environ Res 111:463-467.

23. Nam DH, Adams DH, Flewelling LJ, Basu N. 2010. Neurochemical alterations in lemon shark (Negaprion brevirostris) brains in association with brevetoxin exposure. Aquat Toxicol 99:351-359.

24. Zillioux E, Porcella D, Benoit J. 1993. Mercury cycling and effects in freshwater wetland ecosystems. Environ Toxicol Chem 12:2245-2264.

25. Puls R. 1994. Mineral levels in animal health. Sherpa International, Clearbrook, CA.

26. Beyer W, Heinz G, Redmon-Norwood AW, eds. 1996. Environmental Contaminants in Wildlife. Interpreting Tissue Concentrations. Lewis/ CRC, Boca Raton, FL, USA.

27. Kaiser TE, Reichel WL, Locke LN, Cromartie E, Krynitsky AJ, Lamont TG, Mulhern BM, Prouty RM, Stafford CJ, Swineford DM. 1980. Organochlorine pesticide, $\mathrm{PCB}$, and PBB residues and necropsy data for bald eagles from 29 states-1975-77. Pestic Monit J 13:145-149.

28. Craig T, Connely J, Craig E, Parker T. 1990. Lead concentrations in golden and bald eagles. Wilson Bull 102:130-133.

29. Kenntner N, Tataruch F, Krone O. 2001. Heavy metals in soft tissue of white-tailed eagles found dead or moribund in Germany and Austria from 1993 to 2000. Environ Toxicol Chem 20:1831-1837.

30. Goldstein GW, Asbury AK, Diamond I. 1974. Pathogenesis of lead encephalopathy. Uptake of lead and reaction of brain capillaries. Arch Neurol 31:382-389.

31. Lewis J, Sjöström J, Skyllberg U, Hägglund L. 2010. Distribution, chemical speciation, and mobility of lead and antimony originating from small arms ammunition in a coarse-grained unsaturated surface sand. J Environ Qual 39:863-870.

32. Asakura K, Satoh H, Chiba M, Okamoto M, Serizawa K, Nakano M, Omae K. 2009. Genotoxicity studies of heavy metals: Lead, bismuth, indium, silver and antimony. J Occup Health 51:498-512.

33. Garitano-Zavala A, Cotin J, Borras M, Nadal J. 2010. Trace metal concentrations in tissues of two tinamou species in mining areas of Bolivia and their potential as environmental sentinels. Environ Monit Assess 168:629-644.

34. Zurich MG, Monnet-Tschudi F, Berode M, Honegger P. 1998. Lead acetate toxicity in vitro: Dependence on the cell composition of the cultures. Toxicol In Vitro 12:191-196.

35. Memo M, Lucchi L, Spano PF, Trabucchi M. 1980. Effect of chronic lead treatment on GABA-ergic receptor function in rat brain. Toxicol Lett 6:427-432.

36. Toki H, Namikawa K, Su Q, Kiryu-Seo S, Sato K, Kiyama H. 1998. Enhancement of extracellular glutamate scavenge system in injured motoneurons. J Neurochem 71:913-919. 
37. Suh SW, Aoyama K, Alano CC, Anderson CM, Hamby AM, Swanson RA. 2007. Zinc inhibits astrocyte glutamate uptake by activation of poly(ADP-ribose) polymerase-1. Mol Med 13:344-349.

38. Sorg O, Horn TF, Yu N, Gruol DL, Bloom FE. 1997. Inhibition of astrocyte glutamate uptake by reactive oxygen species: role of antioxidant enzymes. Mol Med 3:431-440.
39. Mahesh VB, Brann DW. 2005. Regulatory role of excitatory amino acids in reproduction. Endocrine 28:271-280.

40. Stamler CJ, Basu N, Chan HM. 2005. Biochemical markers of neurotoxicity in wildlife and human populations: Considerations for method development. J Toxicol Environ Health A 68:14131429. 